\title{
ithlete Heart Rate Variability app: knowing when to train
}

\author{
Lucía Sagarra-Romero, ${ }^{1}$ Mercedes Ruidiaz Peña, ${ }^{2}$ Antonio Monroy Antón, ${ }^{3}$ \\ Santiago Calero Morales ${ }^{4}$
}

${ }^{1}$ Sports, Universidad San Jorge,

Zaragoza, Spain

2Fisiatría y enfermería,

Universidad de Zaragoza,

Zaragoza, Spain

${ }^{3}$ Sports, Universidad de

Valladolid, Madrid, Spain

${ }^{4}$ Sports, Universidad de

las Fuerzas Armadas ESPE,

Sangolquí, Ecuador

Correspondence to

Dr Antonio Monroy Antón,

Universidad de Valladolid, Av.

Filipinas, 16, 28003, Madrid,

Spain;

amonroy111@hotmail.com

Accepted 29 January 2017

Published Online First

20 February 2017
CrossMark

To cite: Sagarra-

Romero L, Ruidiaz

Peña M, Monroy Antón A,

et al. Br I Sports Med

2017:51:1373-1374.

\section{NAME OF THE MOBILE APPLICATION}

ithlete Heart Rate Variability.

\section{CATEGORY OF THE MOBILE APPLICATION \\ Sport and Health.}

\section{PLATFORM}

Android, iOS.

\section{COST}

$€ 8.99(£ 6.99, \$ 8.99)$.

\section{ABOUT THE APP}

'ithlete Heart Rate Variability' app has been scientifically designed for monitoring the body heart rate and give information about when to train and when to rest.

The process of training is stressing and has an impact on health. This app offers a very quick and healthy biofeedback of how stressed, recovered and ready for training your body is. It can also avoid injuries by giving users information related to optimising the effectiveness of their workout sequence.

The app allows users to register their heart rate variability (HRV) and the time gap between the heartbeats when the body is resting, in order to offer users a more precise picture of their overall health and fitness status (figure 1). HRV, the beat-to-beat variation in either heart rate or the duration of the $\mathrm{R}-\mathrm{R}$ interval, has become an increasing important clinical diagnostic tool. For example, Lombardi and Stein ${ }^{1}$ review the relationship between HRV and heart rate turbulence, while Huikuri and Stein $^{2}$ evaluate HRV as a tool for risk assessment in patients recovering from myocardial infarction.

The HRV measurement can be done using a fingertip sensor, a receiver or a Bluetooth smart heart rate, the cost for all of them being around $\$ 80$.

Increased $\mathrm{HRV}$ is related to good health and high level of fitness. However, decreased HRV is linked to stress, fatigue and even burnout.

Only $1 \mathrm{~min}$ measurement will be necessary for obtaining the colour-coded training recommendation: train as usual, train lighter than usual or take a rest day.

Because training is not only the result of workout, this app will allow athletes to maximise their performance and objectify daily fatigue and even burnout.

Users will have useful information connecting the ithlete app to their heart rate sensor (finger sensor, ECG receiver, Bluetooth smart). Although there are in the market other tools that also measure HRV, this app has two main added benefits: the charts provided are much better and the cost is much lower.

\section{USE IN CLINICAL PRACTICE}

In the clinical context, the app can be used to individualise rehabilitation programmes and optimise the recovery of the patients or users. HRV is a measure that can be used to assess the autonomic nervous system (ANS) modulation under physiological conditions, such as wakefulness and sleep conditions, different body positions, physical training and pathological conditions. ${ }^{3}$

Comparing subjective and objective measures will provide a deep knowledge of workout intensity and resting periods. This app allows users to record their lifestyle factors and to build a picture of health and fitness. It also has an interactive chart that lets athletes investigate the relationship between HRV training load and subjective feelings such as sleep, fatigue, muscle soreness, stress level, mood and diet. It is also useful for recording training load or any comments.

The app can be used in clinical context with a supervised and professional staff overview or home-based exercise programme, providing users an additional responsibility about their recovery process and 'body limits. ${ }^{4}$ The feedback it provides is totally understandable to a regular patient.

Finally, this app will allow clients to get motivated and maximise their fitness and performance, increasing their daily physical activity.

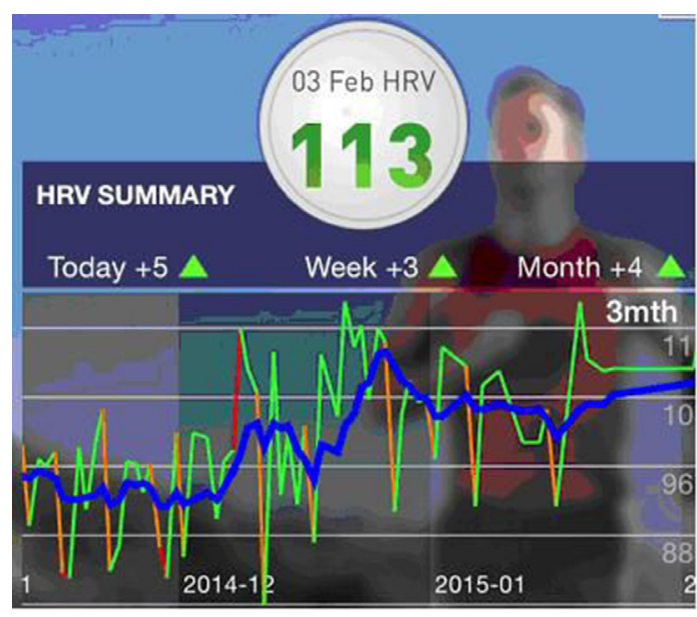

Figure 1 Heart rate variability (HRV) across the training period. 


\section{Mobile app user guides}

\section{PROS}

- Interactive, visual and easy-to-use interface.

- Great for getting motivated by following your progress over time on your smartphone, which should always be more motivating than just training without any kind of feedback.

- Prevents injuries, as HRV may provide a reflection of ANS homeostasis, or the body's stress recovery status. ${ }^{6}$

- All data recorded can be exported via email or Dropbox for analysis.

\section{Cons}

- Not free.

- Requires additional hardware and heart rate sensor.

- Not all mobile devices are compatible with all sensor types.

Competing interests None declared.
Provenance and peer review Not commissioned; externally peer reviewed.

(C) Article author(s) (or their employer(s) unless otherwise stated in the text of the article) 2017. All rights reserved. No commercial use is permitted unless otherwise expressly granted.

\section{REFERENCES}

1 Lombardi F, Stein PK. Origin of heart rate variability and turbulence: an appraisal of autonomic modulation of cardiovascular function. Front Physiol 2011;2:95.

2 Huikuri HV, Stein PK. Clinical application of heart rate variability after acute myocardial infarction. Front Physiol 2012;3:41.

3 Vanderlei LC, Pastre CM, Hoshi RA, et al. Basic notions of heart rate variability and its clinical applicability. Rev Bras Cir Cardiovasc 2009;24:205-17.

4 Noites A, Freitas CP, Pinto J, et al. Effects of a phase IV home-based cardiac rehabilitation program on cardiorespiratory fitness and physical activity. Heart Lung Circ 2016.

5 Harries T, Eslambolchilar P, Rettie R, et al. Effectiveness of a smartphone app in increasing physical activity amongst male adults: a randomised controlled trial. BMC Public Health 2016;16:925.

6 Gisselman AS, Baxter GD, Wright A, et al. Musculoskeletal overuse injuries and heart rate variability: Is there a link? Med Hypotheses 2016;87:1-7. 


\section{BISM ithlete Heart Rate Variability app: knowing when to train}

Lucía Sagarra-Romero, Mercedes Ruidiaz Peña, Antonio Monroy Antón and Santiago Calero Morales

Br J Sports Med 2017 51: 1373-1374 originally published online February 20, 2017

doi: 10.1136/bjsports-2016-097303

Updated information and services can be found at:

http://bjsm.bmj.com/content/51/18/1373

These include:

References This article cites 5 articles, 0 of which you can access for free at: http://bjsm.bmj.com/content/51/18/1373\#BIBL

Email alerting Receive free email alerts when new articles cite this article. Sign up in the service box at the top right corner of the online article.

\section{Notes}

To request permissions go to:

http://group.bmj.com/group/rights-licensing/permissions

To order reprints go to:

http://journals.bmj.com/cgi/reprintform

To subscribe to BMJ go to:

http://group.bmj.com/subscribe/ 